\title{
ІННОВАЦІЙНІ ПІДХОДИ В УПРАВЛІННІ ЗОВНІШНЬОЕКОНОМІЧНОЮ ДІЯЛЬНІСТЮ ПІДПРИЕМСТВ
}

\begin{abstract}
Анотація. В статті проведено дослідження напрямів управління зовнішньоекономічною діяльністю підприємств за допомогою інноващійних підходів. Виявлено, що використання збалансованої системи показників та застосування інноваційних підходів у сфері зовнішньоекономічної діяльності підприемств сприятиме удосконаленню процесу прийняття стратегічних і тактичних рішень та оптимізації діяльності підприємств. Ведення комплексної інноваційної діяльності є вагомим фрактором успішної підприємницької ініціативи та отримання конкурентних переваг над іншими суб'єктами підприємницької діяльності. За умов глобальної кризи саме інноваційна діяльність має стати осередком розробки та впровадження здобутків науково-технічного прогресу. Це актуалізує розробку дієвих заходів з оптимізації управління інноваційною діяльністю вітчизняних підприемств в умовах постійно повторюваних фрінансово-економічних криз.
\end{abstract}

Ключові слова: інновації, зовнішньоекономічна діяльність підприемств, управління, експорт, імпорт.

Horiashchenko Yuliia, Pilgun Alena, Shvets Anastasia University of Customs and Finance

\section{INNOVATIVE APPROACHES IN THE MANAGEMENT OF FOREIGN ECONOMIC ACTIVITIES OF ENTERPRISE}

Summary. The article considers a comprehensive study of the directions and innovative approach in the management of foreign economic activity of enterprises. It is revealed that the application of an innovative approach and the use of a balanced system of indicators in the field of foreign economic activity of enterprises will contribute to improving the process of making strategic and tactical decisions and optimizing the activities of enterprises. Conducting a comprehensive innovation activity is a significant factor in a successful entrepreneurial initiative and obtaining competitive advantages over other business entities. In the context of a global crisis, it is innovation that should become the center of development and implementation of achievements of scientific and technological progress. This actualizes the development of effective measures to optimize the management of innovative activities of domestic enterprises in the context of the financial and economic crisis. Summarizing the existing approaches to assessing innovation potential and taking into account the need to take into account the influence of environmental factors, when analyzing the state of innovation potential of an enterprise, it is necessary to distinguish two main components of the resource, including all resources that are sources of ensuring innovation and determine the ability of the system to implement it; procedural, which, on the one hand, includes internal factors that are stimulators of innovative changes, and on the other determines the ability of the organization to adapt to environmental factors that can create both favorable and unfavorable conditions for the use of innovation resources available to the enterprise. Identifying and evaluating in the structure of innovation potential the component of external conditions (interface component) allows you to overcome one of the most significant shortcomings of most existing methods (overestimating your own innovation capabilities through underestimating external threats) and allows you to determine the level of innovation activity not to carry out a separate analysis of the external environment of the organization, based on the fact that the assessment of factors that directly affect the intensity of innovation activity of the enterprise, is taken into account in the complex indicator of innovation potential of the enterprise.

Keywords: innovations, foreign economic activity of enterprises, management, export, import.

$\Pi$ остановка проблеми. Одним із видів діяльності підприемств є вихід на зовнішні ринки товарів і послуг, який характеризує новий рівень розширення підприемницької діяльності. Крім того, в сучасних умовах все більшого значення набуває інноващійна діяльність, яка також $є$ ідентифрікатором розвитку господарської діяльності підприемств та сприяе підвищенню рівня конкурентоспроможності суб'екта та його предмета діяльності. Своєю чергою, ринкова економіка встановлює ряд показників, які впливають на розвиток зовнішньої торгівлі в країні. Завдання держави полягає у створенні відповідних умов для ведення зовнішньоекономічної діяльності.

На сьогодні перед Україною стоїть завдання переходу «до експорту наукомісткої інноваційної продукції для сталого розвитку та успіху на світових ринках», що задекларовано в Експортній стратегії України «Дорожня карта стратегічного розвитку торгівлі 2017-2021» [12], яка була розроблена за технічної підтримки Міжнародного торговельного центру. Тому використання інновацій у зовнішньоекономічній діяльності підприемств та їх роль в удосконаленні системи управління $є$ актуальним питанням, яке потребуе дослідження та виокремлення обгрунтованих напрямів вирішення.

Аналіз останніх публікацій. Теоретичні та практичні аспекти вище окресленої проблеми досліджені у роботах таких учених, як: Гаркуша О.О., Дунська А.Р., Васильева Л.М., Близнюк Т.П., Зорін О.А., Ксендзук В.В., Гордополов В.Ю., Касич А.О., Любич Б.Б., Каширнікова I.O., Федоренко В.Г. та ін.

Метою статті $€$ дослідження напрямів управління зовнішньоекономічною діяльністю підприємств за допомогою інноваційних підходів та вироблення ефрективних рішень щодо розвитку експорту вітчизняної продукції. 
Виклад основного матеріалу. Майже половина ВВП України формуеться за рахунок експорту, а тому стратегічним завданням для країни є масштабне зростання присутності її на зовнішніх ринках. Близько половини ВВП розвинених країн світу формуеться за рахунок сектору малого i середнього підприемництва. До $70 \%$ вітчизняного експорту - сировинна продукція АПК, металургійної, хімічної промисловості та мінеральної сировини [12]. Отож, основними економічними акторами на зовнішньому ринку є великі підприемства, тоді як питома вага малих і середніх підприемств у структурі підприемництва складає майже $97 \%$, а отже, держава має створити умови їх активного включення в експортну діяльність.

В економічних зв’язках України із зарубіжними державами використовуеться науковотехнічне співробітництво (торгівля патентами, ліцензіями, технічним досвідом "ноу-хау» тощо), яке сприяе прискоренню темпів економічного розвитку, втіленню у практику найновіших технічних досягнень, раціональному використанню природних ресурсів, автоматизації і механізації технологічних процесів, скороченню строків будівництва сучасних підприемств, підвищенню ефективності капіталовкладень, розширенню сфери міжнародних відносин. Науково-технічне співробітництво здійснюеться у формах [5]:

- матеріальній, тобто через обмін продукцією, насамперед наукоємною, створеною за найновішими технологіями;

- нематеріальній - у вигляді креслень, формул, обміну інформацією, літературою та ін.;

- послуг фохівців і технічного персоналу в галузі менеджменту, маркетингу, контролю за якістю.

Науково-технічне кооперування між фрірмами здійснюеться у формі консалтингу (технічного консультування та експертизи проектів), лізингу (оренди промислового і науково-дослідного устаткування).

У зовнішньоекономічних зв'язках України використовуеться i така форма економічного співробітництва, як кредити. В сучасних умовах нестабільності економічного розвитку Україна зацікавлена в надходженні іноземних інвестицій в українську економіку. На перспективу Україна зможе надавати цільові кредити в національній валюті зарубіжним державам, підприемствам та іншим споживачам під закупівлю вітчизняної машинно-технічної продукції. Таке кредитування іноземних споживачів сприятиме зовнішньому конвертуванню української грошової одиниці [2].

Створення спільних підприемств - одна 3 форм економічного співробітництва України із зарубіжними партнерами. Ці підприемства діють самостійно, наділені широкими правами для здійснення експортних та імпортних операцій. Спільні підприемства погоджують ціни на спільно вироблену продукцію і укладають відповідні контракти. Їх прибуток розподіляеться між учасниками пропорційно вкладу в статутний фонд. На території України діе понад 2,5 тис. спільних підприемств. За участю фірм США створено 120 Німеччини - 40, Австрії - 22 та ряду інших країн. Найбільше їх у місті Києві (204) та Одеській області (143).
Різними е профрілі спільних підприемств. Так, львівське виробниче об'єднання «Конвеєр» і болгарсько-угорське товариство «Інтрасмаш», а також гомельське виробниче об'єднання «Гідроавтоматика" та завод "Данувія» (У горщина) уклали договір про прямі зв'язки щодо спільного проектування і виробництва автоматизованих транспортно-складських систем і засобів гідроавтоматики.

Налагоджуе стосунки із зарубіжними фірмами Міністерство аграрної політики України. Заслуговуе на увагу співробітництво з фрірмою BASF (ФPH) у галузі впровадження інтенсивної технології виробництва сої на основі застосування хімічних препаратів фірми [3].

Перспективним напрямком розширення зовнішньоекономічних зв'язків е створення спеціальних зон "вільного підприемства» на території України (в районі Одеси, на Закарпатті та в деяких інших місцях). Такі зони в Україні з часом сприятимуть прискоренню розвитку їі економіки на основі створення умов для залучення іноземного капіталу.

Розвиток зовнішньоекономічної діяльності українських підприемств відбувався в складних умовах втрати ринків збуту, надлишку товарів та послуг, відсутності власних кваліфікованих фахівців, низької конкурентоспроможності продукції, нових принщипів цінностей, нових поколінь тощо.

Складність ситуащії полягає в тому, що для багатьох підприемств цілі щодо пошуку нових перспективних ринків збуту, активізації співробітництва зі світовими галузевими лідерами, формування обсягу інвестицій для активної експортної експансії не розглядались та не мали необхідного ресурсного забезпечення. За таких умов для забезпечення системності зовнішньоекономічної діяльності та, перш за все, її стратегічної орієнтації необхідно розробити комплекс заходів та етапів управління даною сферою. Для імплементації інноваційного підходу в сферу управління зовнішньоекономічною діяльністю використаємо основні підходи, представлені у роботах $[1 ; 2]$.

Україна бере участь в економічному співробітництві також з країнами, що розвиваються. У наданих за часів СРСР цим країнам кредитах на пільгових умовах з відшкодуванням протягом 10-12 років частка України становила майже \$ 18 млрд. Традиційні товари експорту країн, що розвиваються, - бавовна, джут, вовна, apaxic, рис, оливкова олія, натуральний каучук, какао-боби, кава, цитрусові, тютюн та ін. Україна вивозить до цих країн машини та промислове устаткування. Так, вантажні автомобілі Кременчуцького заводу поставляються до Індії, Латинської Америки, на Близький Схід; помпи із Сумського заводу - до Індії, Пакистану, Сирії; машини, устаткування, прилади для африканських, азіатських і латиноамериканських країн виготовляють 3 урахуванням ї роботи в умовах тропічного клімату [4].

Підписано угоду про постачання нафрти і газу з Ірану в Україну з цією метою створено Українсько-ірансько-азербайджанську компанію, яка у майбутньому має збудувати систему трубопроводів через Росію в Україну (по $45 \%$ внески України та Ірану і 10 \% - Азербайджану) [1]. Уго- 
да розрахована на 15 років Україна поставлятиме до Ірану машини та обладнання для гірничодобувної і металургійної промисловості, братиме участь у реконструкції металургійних підприемств, доріг та морських портів.

Підписано угоду між Україною і Тунісом про співробітництво в галузі іригації, за якаю на туніських іригаційних спорудах працюватимуть українські фрахівці. Туніс постачатиме Україні фосорорити.

Останнім часом право на здійснення зовнішньоекономічних операцій надано окремим підприемствам i організаціям, що сприяло підвищенню активності у зовнішньоекономічній сорері. Зареєстровано більш як 30 тис. учасників зовнішньоекономічних зв'язків.

Експорт українських товарів в інші країни світу у 2017 рощі складае 72,4\% всього обсягу експорту товарів, в т.ч. до країн СС - 31,5\%, у 2018 рощі експорт товарів з України в інші країни світу складає 79,5\%, в т.ч. до країн $\mathrm{CC} \mathrm{-} \mathrm{34,1 \% ,}$ у 2019 році відповідно 83,6\% та $37,2 \%$, тобто, доля експорту українських товарів до країн ЄС щорічно збільшуеться (рис. 1).

Імпорт товарів в Україну з інших країн світу у 2017 рощі складає 68,2\%, в т.ч. 3 країн ЄC - 38,7\%, у 2018 році імпорт товарів з інших країн світу складае $72,1 \%$ всього товарного імпорту, в т.ч. 3 країн СС - 40,9\%, у 2019 році відповідно 78,2\% та $43,7 \%$, тобто щорічно спостерігаеться підвищення долі імпорту товарів з країн ЄС (рис. 2).

Загальний експорт товарів у 2019 рощі складає 95,4\% обсягів 2018 року, імпорту - 104,6\% від рівня 2018 року. Найбільшими експортерами товарів природно є м. Київ, Дніпропетровська, Донецька та Запорізька області.

Детально обсяги експорту - імпорту товарів 3 країнами ЄС у 2019 році наведено у таблиці (таблиця 1).

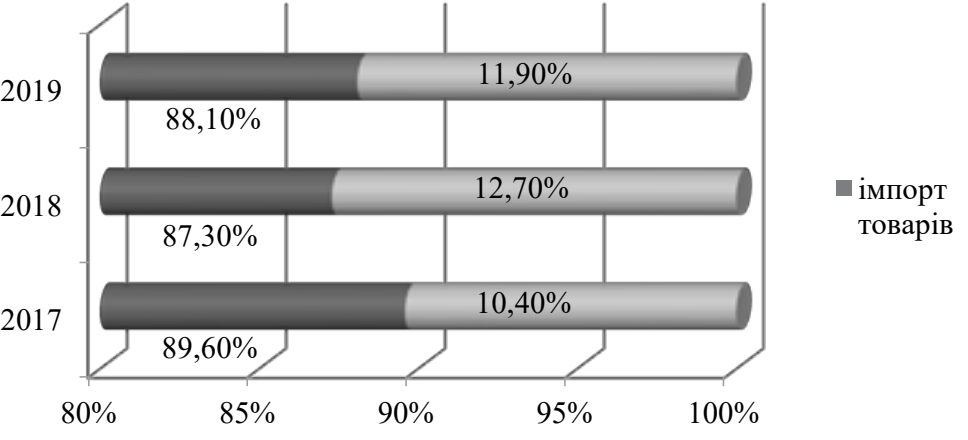

Рис. 2. Структура загального імпорту у 2017-2019 рр. (\%)

Загальне сальдо торгівлі товарами 3 країнами ЄC у 2019 році має від'ємне значення 2314,9 млн. дол. США. Доля експорту українських товарів перевищуе долю товарного імпорту (сальдо позитивне) при торгівлі 3 Болгарією, Іспанією, Італією, Кіпром, Латвією, Нідерландами, Португалією, Румунією, Словаччиною, Хорватією і Чехією. Найбільші обсяги експорту українських товарів та імпорту - до (3) Італії, Німеччини і Польщі, крім того, багато товарів Україна імпортуе з Угорщини.

Аналіз ЗЕД підприемств являе собою комплексне системне вивчення проведення між-

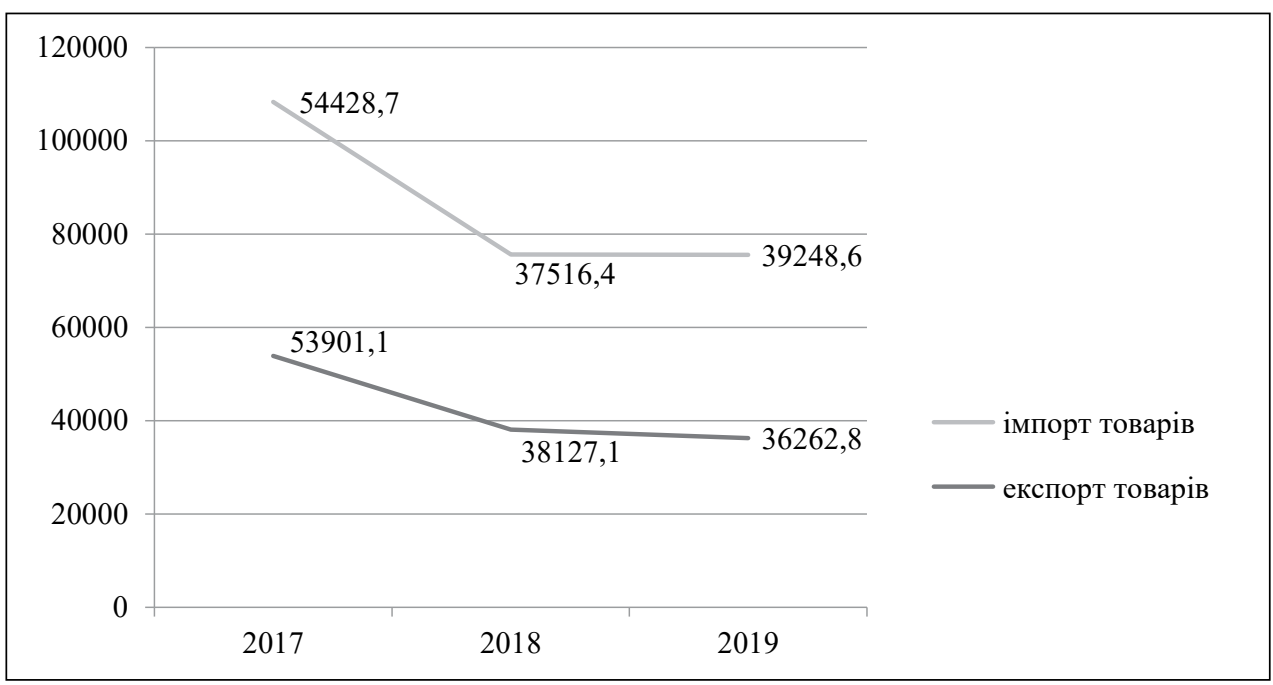

Рис. 3. Динаміка експорту - імпорту товарів у 2017-2019 рр. (млн. дол. США)

Джерело: складено авторами за даними Державної служби статистики Украйни 
Зовнішня торгівля України товарами з країнами СС у 2019 році

\begin{tabular}{|c|c|c|c|}
\hline Країни & Експорт & Імпорт & Сальдо \\
\hline Усього по країнах СС & 13015209,7 & 15330156,2 & $-2314946,5$ \\
\hline \multicolumn{4}{|l|}{ у тому числі } \\
\hline Австрія & 347167,2 & 369635,3 & $-22468,1$ \\
\hline Бельгія & 296848,8 & 366777,5 & $-69928,7$ \\
\hline Болгарія & 419500,8 & 253119,2 & 166381,6 \\
\hline Велика Британія & 367897,3 & 570127,8 & $-202230,5$ \\
\hline Греція & 153776,0 & 238558,9 & $-84782,9$ \\
\hline Данія & 144675,3 & 147614,0 & $-2938,7$ \\
\hline Естонія & 66205,7 & 77499,2 & $-11293,5$ \\
\hline Ірландія & 59182,6 & 75396,4 & $-16213,8$ \\
\hline Іспанія & 1043602,6 & 440750,5 & 602852,1 \\
\hline Італія & 1979843,6 & 976327,8 & 1003515,8 \\
\hline Кіпр & 61526,1 & 16922,9 & 44603,2 \\
\hline Латвія & 150267,1 & 87144,8 & 63122,3 \\
\hline Литва & 236300,5 & 552614,3 & $-316313,8$ \\
\hline Люксембург & 5883,8 & 57729,5 & $-51845,7$ \\
\hline Мальта & 12237,0 & 16359,3 & $-4122,3$ \\
\hline Нідерланди & 905655,0 & 452611,8 & 453043,2 \\
\hline Німеччина & 1328677,4 & 3975626,5 & $-2646949,1$ \\
\hline Польща & 1977329,6 & 2324048,2 & $-346718,6$ \\
\hline Португалія & 320541,1 & 45166,6 & 275374,5 \\
\hline Румунія & 569947,1 & 318202,3 & 251744,8 \\
\hline Словаччина & 468528,8 & 346331,1 & 122197,7 \\
\hline Словенія & 16261,0 & 128876,4 & $-112615,4$ \\
\hline Угорщина & 909721,0 & 1608536,1 & $-698815,1$ \\
\hline Фінляндія & 48037,7 & 222957,3 & $-174919,6$ \\
\hline Франція & 497949,4 & 892786,2 & $-394836,8$ \\
\hline Хорватія & 26086,5 & 15147,9 & 10938,6 \\
\hline Чехія & 540950,6 & 479718,5 & 61232,1 \\
\hline Швеція & 60609,9 & 273534,6 & $-212924,7$ \\
\hline
\end{tabular}

Джерело: складено авторами за даними Державной служби статистики Украӥни

народних комерційних операцій, фрункціонування відповідних структурних підрозділів підприємства 3 метою об'єктивної оцінки досягнутих результатів, виявлення причин відхилення та шляхів підвищення ефрективності зовнішньоекономічної діяльності [7].

Аналіз едективності зовнішньоекономічної діяльності потребує використання доступної інформації, та зумовлюе утворення певних рівнів обчислення [2]:

- перший рівень передбачає визначення суми прибутку, рівня прибутку до загального обсягу експорту, рентабельності експорту стосовно витрат на здійснення таких операцій на основі бухгалтерської звітності.

- на другому рівні використовуеться додаткової інформації у межах управлінського обліку, i визначаються: граничні (маржинальні) показники обсягів експорту, змінних витрат та прибутку у розрахунку на одиницю продукції або на одну поставку чи експортну операцію;

- гранична (маржинальна) рентабельність експорту товару (співвідношення граничного прибутку з граничними змінними витратами);

- точка беззбитковості товару, що експортується (відношення постійних витрат до маржи- нального прибутку); точка беззбитковості для порівняння обсягів експорту з наявною виробничою потужністю підприемства та ін.

- третій рівень передбачає використання внутрішньої та зовнішньої інформації про стан реалізації конкретних товарів на міжнародному ринку, і визначаються показники, які дозволяють обгрунтовувати стратегію зовнішньоекономічної діяльності підприемства.

Вибір методики аналізу залежить від мети аналізу, наявності інформащї, часу проведення аналізу та управлінського рівня: на нижчих щаблях управління вирішуються більш прості проблеми і використовуються спрощені методики аналізу, і навпаки, чим вищий рівень управління, тим виникають складніші проблеми, які потребують застосування більш досконалих методик аналізу.

Основними напрямами вдосконалення 30внішньоекономічної діяльності підприемства $\epsilon$ такі [2]:

- аналіз едективності зовнішньоекономічної діяльності підприємств та розробка інноваційного підходу ефрективного розвитку;

- виявлення напрямів удосконалювання системи управління та планування зовнішньоекономічних зв'язків на рівні підприемства; 
- вивчення сучасних аналітичних підходів i методів дослідження зовнішньоторговельних ринків;

- розробка організаційно-економічних заходів підвищення конкурентоздатності експортної продукції;

- розробка заходів підвищення едективності експортної діяльності вітчизняних товаровиробників;

- формування системи довгострокових цілей зовнішньоекономічної діяльності;

- розробка міжнародної маркетингової стратегії.

Вітчизняний ринок недостатньо місткий та не здатний поглинути всю запропоновану продукцію, що зумовлюе необхідність підприемствам виходити на зовнішні ринки, конкуренція на яких значно вища. Тому для забезпечення ефрективної зовнішньоекономічної діяльності підприємству необхідний єдиний стратегічний напрямок розвитку, згідно з яким воно зможе досягти довгострокових конкурентних переваг [1].

Для розробки інноваційного підходу необхідно зробити комплексний аналіз діяльності підприємства. По-перше, необхідно провести комплексний аналіз ефективності ЗЕД $з$ використанням збалансованої системи показників на засадах фінансово-економічного аналізу та складання матриці SWOT, згрупувати економічні показники в збалансовану систему показників. По-друге, треба провести аналіз зовнішнього середовища, який включає в себе оцінку постачальників, конкурентів та споживачів, а також включає аналіз запропонованих підприемством та конкурентами товарів з метою виявлення можливості заміни товару та стадії його життевого циклу. По-третє, для визначення ринку привабливості зовнішньоекономічної діяльності підприемства доцільно провести матричний аналіз [3].

Висновки. В умовах втрати традищійних ринків через пандемію хвороби COVID-19 і спричинені нею кризові явища, необхідність пошуку ефрективних рішень для розвитку експорту вітчизняної продукції значно підсилюеться.

Можна зазначити, що едрективна зовнішньоекономічна діяльність сприяе підвищенню конкурентоспроможності українських товарів на світових ринках, відтворенню експортного потенціалу країни, формуванню раціональної структури експорту й імпорту, підвищенню конкурентоспроможності українських товарів на світових ринках, забезпеченню економічної безпеки України, залученню іноземних інвестицій на взаємовигідних умовах.

На сьогодні, важливим фрактором, що стримує розвиток зовнішньоекономічної діяльності підприемств $є$ неефективний ступінь впливу на прийняття управлінських рішень і досягнення підприемством позитивних зрушень від втілення у життя результатів діяльності підприемства.

Отже, застосування інноваційного підходу та використання збалансованої системи показників у сорері ЗЕД підприємств сприятиме удосконаленню процесу прийняття стратегічних і тактичних рішень та оптимізації діяльності підприемств.

\section{Список літератури:}

1. Гаркуша О.О. Ефективність зовнішньоекономічної діяльності підприемств : автореф. дис. на здобуття наук. ступеня к.е.н. URL: http://masters.donntu.edu.ua/2017/fem/garkusha/diss/index.htm

2. Дунська А.Р. Особливості формування інноваційної стратегії в системі управління зовнішньоекономічною діяльністю підприемства. URL: http://nbuv.gov.ua/UJRN/evntukpi_2015_12_62

3. Зовнішньоекономічна діяльність підприемства : навч. посіб. / за ред. О.В. Шкурупій. Київ : Центр учбової літератури, 2012. 248 с.

4. Дунська А.Р. Зовнішньоекономічна діяльність: теорія і практика : навч. посіб. Київ : Кондор, 2017. 688 с.

5. Зоріна О.А., Ксендзук В.В., Гордополов В.Ю. Використання інновацій та функціонування системи управління діяльністю підприемств зовнішньої торгівлі. 2018.

6. Касич А.О. Втілення концепції інноваційного підходу в практику вітчизняних підприемств. Бізнес-Інфборл. 2014. № 11. C. 290-294.

7. Касич А.О. Стратегія управління експортним потенціалом підприемств важкого автомобілебудування. URL: http://www.economy.nayka.com.ua/

8. Каширнікова I.О. Підхід до визначення впливу зовнішніх фракторів на управління інноваційним потенціалом будівельного. URL: http://nbuv.gov.ua/UJRN/ipd_2016_7_16

9. Крейдич I.M. Діагностика впливу зовнішніх та внутрішніх чинників на процес інноваційно-інвестиційного забезпечення стійкого розвитку промислових підприемств. URL: http://nbuv.gov.ua/UJRN/efek_2013_2_80

10. Любич Б.Б. Інноваційне управління на основі показників оцінки стану зовнішньоекономічної діяльності підприемства. URL: http://nbuv.gov.ua/UJRN/Mimi_2011_2_21

11. Менеджмент зовнішньоекономічної діяльності : підручник / за ред. О.А. Кириченка. Київ: Знання, 2018. $518 \mathrm{c}$.

12. Про схвалення Експортної стратегї̈ України («дорожньої карти» стратегічного розвитку торгівлі) на 2017-2021 роки: розпорядження Кабінету Міністрів України, в ред. від 17.09.2020. URL: https://zakon.rada.gov.ua/laws/show/1017-2017-\%D1\%80\#Text

\section{References:}

1. Garkusha O.A. (2017) Efficiency of foreign economic activity of enterprises. Abstract of the dissertation for the degree of candidate of Economic Sciences. Available at: http://masters.donntu.edu.ua/2017/fem/garkusha/diss/ index.htm (in Ukrainian)

2. Dunskaya A.R., Zinchenko D.V. (2015) Osobennosti formirovaniya innovatsionnoi strategii $v$ sistemy upravleniya vneshnoeconomicheskoy deyatel'nosti predprinimatelstva. Available at: http://nbuv.gov.ua/UJRN/ evntukpi_2015_12_62 (in Ukrainian)

3. Foreign economic activity of the enterprise: textbook (2012) / edited by O.V. Shkurupiy. Kyiv: Center for educational literature. (in Ukrainian)

4. Dunskaya A.R. (2017) Foreign Economic Activity: Theory and practice: textbook. Kyiv: Condor, 688 p. (in Ukrainian) 
5. Zorina O.A., Ksendzuk V.V., Gordopolov V.Yu. (2018) Use of innovations and functioning of the system of management of foreign trade enterprises. (in Ukrainian)

6. Kasich A.A. (2014) Implementation of the concept of innovative approach in the practice of domestic enterprises. Biznes-Inform, no. 11, pp. 290-294. (in Ukrainian)

7. Kasich A.A., Tsygan R.M., Nazarenko K.I. (2016) Strategy of managing the export potential of heavy automobile enterprises. Effective economy, no. 12. Available at: http://www.economy.nayka.com.ua/ (in Ukrainian)

8. Kashirnikova I.A. (2016) Approach to determining the influence of external factors on the management of innovative potential of a construction enterprise. Investments: practice and experience. Available at: http://nbuv.gov.ua/UJRN/ipd_2016_7_16 (in Ukrainian)

9. Kreidich I.M., Nakonechnaya O.S., Shvets K.M. (2013) Diagnostics of the influence of external and internal factors on the process of innovative and investment support for sustainable development of industrial enterprises. Efficient economy, no. 2. Available at: http://nbuv.gov.ua/UJRN/efek_2013_2_80 (in Ukrainian)

10. Lyubich B.B. (2011) Innovative management on the basis of indicators of assessment of the state of foreign economic activity of the enterprise. Available at: http://nbuv.gov.ua/UJRN/Mimi_2011_2_21 (in Ukrainian)

11. Management of foreign economic activity: textbook (2018) / Ed. O.A. Kirichenko. Kyuv: Znanie publ., 518 p.

12. Pro skhvalennia Eksportnoi stratehii Ukrainy («dorozhnoi karty» stratehichnoho rozvytku torhivli) na 2017-2021: rozporiadzhennia Kabinetu Ministriv Ukrainy, v red. vid 17.09.2020. Available at: https://zakon.rada.gov.ua/laws/show/1017-2017-\%D1\%80\#Text (in Ukrainian) 